\title{
Erratum to: Fat tissue is not a reservoir for radiocesium in wild boars
}

\author{
Georg Steinhauser ${ }^{1} \cdot$ Christian Knecht $^{2} \cdot$ Wolfgang Sipos $^{2}$
}

Published online: 30 August 2017

(C) Akadémiai Kiadó, Budapest, Hungary 2017

\section{Erratum to: J Radioanal Nucl Chem (2017) 312:705-709$$
\text { DOI 10.1007/s10967-017-5257-3 }
$$

The article "Fat tissue is not a reservoir for radiocesium in wild boars", written by "Georg Steinhauser, Christian Knecht and Wolfgang Sipos", was originally published Online First without open access. After publication in volume 312, issue 3, page 705-709 the authors decided to opt for Open Choice and to make the article an open access publication. Therefore, the copyright of the article has been changed to (c) The Author(s) 2017 and the article is forthwith distributed under the terms of the Creative Commons Attribution 4.0 International License (http://creative commons.org/licenses/by/4.0/), which permits use, duplication, adaptation, distribution and reproduction in any medium or format, as long as you give appropriate credit to the original author(s) and the source, provide a link to the Creative Commons license, and indicate if changes were made.

The online version of the original article can be found under doi:10.1007/s10967-017-5257-3.

Georg Steinhauser

steinhauser@irs.uni-hannover.de

1 Institute of Radioecology and Radiation Protection, Leibniz

Universität Hannover, Herrenhäuser Str. 2, 30419 Hannover,

Germany

2 Clinical Department for Farm Animals and Herd

Management, University of Veterinary Medicine Vienna,

Veterinärplatz 1, 1210 Vienna, Austria 